\title{
A Pilot Project for Expansion of the External Quality Assessment Program in Transfusion Medicine: Extended Antigen Typing
}

\author{
Yousun Chung ${ }^{\oplus}$, Jin Seok Kim ${ }^{2 \oplus}$, John Jeongseok Yang ${ }^{2 \oplus}$, Hyungsuk Kim ${ }^{3 \oplus}$, Sang-Hyun Hwang ${ }^{2 \oplus}$, \\ Heung-Bum $\mathrm{Oh}^{2 \oplus}$, and Dae-Hyun $\mathrm{Ko}^{2 \oplus}$ \\ ${ }^{1}$ Department of Laboratory Medicine, Kangdong Sacred Heart Hospital; ${ }^{2}$ Department of Laboratory Medicine, Asan Medical

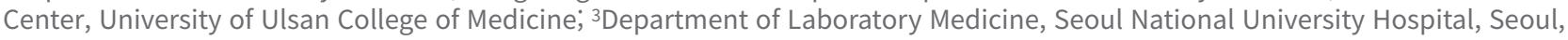 \\ Korea
}

Corresponding author:

Dae-Hyun Ko

Department of Laboratory Medicine, Asan Medical Center, University of Ulsan College of Medicine, 88 Olympic-ro 43gil, Songpa-gu, Seoul 05505, Korea Tel +82-2-3010-4504

E-mail daehyuni1118@amc.seoul.kr

Received: January 28, 2021

Revised: February 24, 2021

Accepted: February 25, 2021

This is an Open Access article distributed under the terms of the Creative Commons Attribution Non-Commercial License (http://creativecommons.org/licenses/ by-nc/4.0) which permits unrestricted non-commercial use, distribution, and reproduction in any medium, provided the original work is properly cited.
Background: As the need for expansion of the external quality assessment (EQA) scheme for transfusion medicine in Korea has increased, we performed a pilot project of extended antigen typing for Lewis, Duffy, and Kidd antigens. Methods: We sent EQA materials to participant laboratories for Lewis, Duffy, and Kidd antigen typing in October 2020. Participants were asked to enter the agglutination titers, methodologies, and results of Lewis, Duffy, and Kidd antigen typing on the Korean Association of External Quality Assessment Service website.

Results: For Lewis antigen typing, the intended result was Le(a-b-); 20 participants (95.2\%) responded as Le(a-b-), and only one (4.8\%) responded as Le(a-b+). For the Duffy antigen typing test, the intended result was Fy $(a+b-)$, and all 20 participants $(100 \%)$ responded as Fy(a+b-). For the Kidd antigen typing test, the intended result was $\mathrm{Jk}(\mathrm{a}+\mathrm{b}+)$, and all 22 participants $(100 \%)$ responded as $\mathrm{Jk}(\mathrm{a}+\mathrm{b}+)$.

Conclusions: As the pilot project was successfully executed, extended antigen typing for Lewis, Duffy, and Kidd antigens has been included in the Korean Association of External Quality Assessment Service on transfusion medicine since 2021.

(Lab Med Qual Assur 2021;43:87-93)

Key Words External quality assessment, Transfusion medicine, Extended antigen typing
서론

대한임상검사정도관리협회에서는 2016년부터 차세대 정도관 리프로그램을 시행하기 시작하여, 이전에 70 여 개에 불과하던 신 빙도조사 항목을 300 종 이상으로 확장하여 국내의 외부정도관리 를 주도하고 있다[1-10].

그러나 수혈의학분야에서는 상대적으로 다른 분야에 비하여 검사종목 확대가 거의 이루어지지 못했다. 현재 4 개의 수혈의
학프로그램에서 10 가지 검사항목에 대해 신빙도조사를 수행하 고 있다: (1) 일반수혈검사: ABO typing, RhD typing, blood crossmatching, (2) 수혈항원검사, 특수: ABO subgroup typing, Rh CcEe antigen test, weak D test, (3) 수혈항체검 사, 일반: direct antiglobulin test, unexpected antibody screening, (4) 수혈항체검사, 특수: ABO antibody titration, unexpected antibody identification. 본 연구진에서는 2019년 국내외 자료조사 및 전문가 자문을 시행하여 국내 수혈의학분야 
신빙도조사사업의 확장 필요성에 대하여 검토한 바 있다[11]. 이 에 따라 $\mathrm{ABO}, \mathrm{Rh}$ 이외의 항원에 대한 항원형 검사, 항-Rh 항체역 가검사, 용출검사 등에 대한 외부정도관리 확대의 임상적 요구가 있음을 알게 되었다.

본 연구에서는 국내 수혈의학분야 외부정도관리 확대의 첫 단 계로 Lewis, Duffy, Kidd 혈액형 항원에 대한 항원형 검사 시범사 업을 실시하여 운영상 보완해야 할 부분이 없는지 점검하였고, 그 결과를 보고하고자 한다.

\section{재료 및 방법}

\section{1. 시범사업 참여 수요 조사}

세 항원에 대한 시범사업에 대한 참여 수요를 파악하기 위하 여 2020년 1차 수혈의학분야 정도관리 결과 입력 시에 Lewis, Duffy, Kidd 항원형 검사에 참여할 의사가 있는지 의사를 입력할 수 있도록 결과 입력창을 수정하였다.

\section{2. 물질 제조 및 발송}

2020년도 10월에 시행되는 수혈의학분야 2차 신빙도조사를 위한 물질 제조 시에 기존의 Rh CcEe 항원형 검사용 물질(BGS20-05)을 공용으로 하여 Lewis, Duffy, Kidd 항원검사를 실시 하도록 안내하였다(Fig. 1). 해당 물질은 공급혈액원으로부터 제
공받은 폐기예정인 혈액을 이용하여 제조하였으며[1], 수혈의학 분야 2차 물질 발송 시에 같이 발송되었다. 해당 물질의 각 항원 형은 anti-Fya (DIAGAST, Loos, France), anti-Fyb (DIAGAST), anti-Lea (DIAGAST), anti-Le (DIAGAST), anti-Jka (DIAGAST), anti-Jkb (DIAGAST) 시약을 이용하여 검증하고 이를 의도된 정답 (intended response)으로 설정하였다.

\section{3. 결과 입력 및 판정}

세 가지 항원형에 대한 결과 입력은 대한임상검사정도관리협회 신빙도조사사업 홈페이지(http://eqas.keqas.org/)에 기존 기관 회원 아이디를 이용하여 접속, 결과를 입력하도록 하였다. 결과 입 력은 각 항원별로 응집강도 및 검사법, 최종 판정을 입력할 수 있 도록 하였다(Fig. 2).

결과 판정은 기존의 RhCCEe 항원과 동일한 원칙으로, 의도된 정답(intended response)과 동일한 결과를 입력한 기관이 $80 \%$ 이상일 경우 해당 기관은 적합(acceptable)한 것으로 판정하였 다. 혈구 응집강도는 대한임상검사정도관리협회의 반정량검사 판 정기준에 의거하여 최빈값노한 단계 빈도의 합이 $80 \%$ 이상인 범 위를 의도된 정답으로 선정하여 결과를 판정하였고, 이것이 $80 \%$ 미만인 경우 이웃한 등급의 빈도가 큰 것을 계속 합하여 빈도의 합 이 $80 \%$ 넘으면 확장한 범위를 의도된 정답으로 선정하였다. 같은 기준 분류검사법을 사용하는 기관이 10 개 미만일 경우 code 501

3) 수혈의학 프로그램 구성 (※ 자세한 프로그램별 검체유형, 검사항목 및 검체번호는 마지막 장 참고)

\begin{tabular}{|c|c|c|c|c|}
\hline 프로그램명 & 검체번호 & 검체성상 & 검사항목 & 특이사항 \\
\hline \multirow{6}{*}{ 일반수혈검사 } & BB-20-07 & \multirow{3}{*}{ 전혈 } & \multirow{3}{*}{$\mathrm{ABO}$ cell typing + serum typing $\&$ RhD typing } & \\
\hline & BB-20-08 & & & \\
\hline & BB-20-09 & & & \\
\hline & BB-20-10 & \multirow{3}{*}{ 액상 } & \multirow{3}{*}{ BB-20-08 \& Blood crossmatchi } & \\
\hline & BB-20-11 & & & $\begin{array}{l}\text { BB-20-08 검제를 교자 } \\
\text { 시ㅎㅓㅓㅇㅛ 혁구로 사요 }\end{array}$ \\
\hline & BB-20-12 & & & \\
\hline \multirow{6}{*}{$\begin{array}{c}\text { 수혈항원검사, } \\
\text { 특수 }\end{array}$} & BGS-20-04 & \multirow{6}{*}{ 혈구부유액 } & ABO subgroup typing & \\
\hline & \multirow{4}{*}{ BGS-20-05 } & & Rh CcEe antigen test & \\
\hline & & & Duffy antigen test (시범항목) & \\
\hline & & & Lewis antigen test (시범항목) & \\
\hline & & & Kidd antigen test (시범항목) & \\
\hline & BGS-20-06 & & Weak D test & \\
\hline \multirow{6}{*}{$\begin{array}{c}\text { 수혈항체검사, } \\
\text { 일반 }\end{array}$} & BBG-20-07 & \multirow{3}{*}{ 액상 } & \multirow{3}{*}{ Unexpected antibody (screening) } & \\
\hline & BBG-20-08 & & & \\
\hline & BBG-20-09 & & & \\
\hline & BBG-20-10 & \multirow{3}{*}{ 혈구부유액 } & \multirow{3}{*}{ Direct anti-human globulin te } & \\
\hline & BBG-20-11 & & & \\
\hline & BBG-20-12 & & & \\
\hline \multirow{3}{*}{$\begin{array}{c}\text { 수혈항체검사, } \\
\text { 특수 }\end{array}$} & BBS-20-04 & \multirow{2}{*}{ 액상 } & \multirow{2}{*}{ Unexpected antibody (identification) } & \\
\hline & BBS-20-05 & & & \\
\hline & BBS-20-06 & 액상 & $\mathrm{ABO}$ antibody titration & \\
\hline
\end{tabular}

Fig. 1. Program guide for the Korean Association of External Quality Assessment Service (excerpt). Lewis, Duffy, and Kidd antigen typing tests were newly introduced in the transfusion medicine program in 2020 as a pilot project. 
2020 년 02 차/ 수혈 항원검사, 특수

\begin{tabular}{|c|c|c|}
\hline 검사명[ 단위 ] & \multicolumn{2}{|c|}{ BGS-20-05 } \\
\hline Lewis antigen test & & \\
\hline - Le(a) 항원 & $1+$ & 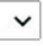 \\
\hline - Le(b) 항원 & & $\checkmark$ \\
\hline - 판정 & Le $(a+b+)$ & v \\
\hline
\end{tabular}

Fig. 2. Page on the Korean Association of External Quality Assessment Service website (http://eqas. keqas.org/) for results of extended antigen typing (excerpt). It was required to enter the agglutination titers, the methodologies, and the final results of Lewis, Duffy and Kidd antigen typing tests.
(해당 항목의 참가기관 수가 적어 평가를 할 수 없습니다)의 예외 코드를 부여하였다. 다만, 본 회차에서는 시범사업임을 고려하 여 내부적으로 정답 판정은 평가하였으나 기관별 결과보고서에는 code 507(시범항목으로 평가에서 제외)로 기재하여 발송하였다.

\section{결과}

\section{1. 시범사업 참여 수요 조사}

2020년도 1차 수혈의학 결과 입력 시에 시범사업 참여 의향을 조사한 결과, Lewis, Duffy, Kidd 항원형 검사에 대하여 각각 32, 32,33 기관에서 참여 의사를 밝혔다. 이 중 28 개의 기관이 세 가지 항원 모두에 대해 참여의사를 밝혔다.

\section{2. 결과 판정}

2020년도 2차 수혈의학 신빙도조사에서 Lewis, Duffy, Kidd 항원검사는 각각 $21,22,23$ 개 기관이 참여하였다. 항원형 검사를 위한 신빙도조사 물질의 Lewis 항원형은 Le(a-b-)인 혈구로, 정 답률은 95.2\% (20/21)였다. 참여기관에서 사용하고 있는 Lewis 항원검사법은 원주응집법 또는 시험관법을 각각 3 기관, 18 기관에 서 사용하고 있었다. Le(a) 항원에 대해서는 참여기관 모두에서 음 성 결과를 보고하였으나, $\mathrm{Le}(\mathrm{b})$ 항원에서는 시험관법을 사용하는 기관 중 한 기관 $(5.6 \%, 1 / 18)$ 에서 $1+$ 의 결과를 입력하였다. 이에 따라 최종 판정에서는 Le(a-b+)를 입력한 한 기관을 제외하고는 모두 acceptable 판정을 받았다(Table 1). 원주응집법을 사용한 3 개 기관의 경우 참가기관 수가 적어 code 501에 해당되나, 모든 기관에서 Le(a), Le(b) 항원에 대해 음성 결과를 보고하였다.

Duffy 항원의 경우, 참여한 22 개 기관 중 한 기관에서는 Fy(a)
Table 1. Results of Lewis antigen typing $(n=21)$

\begin{tabular}{|c|c|c|c|c|}
\hline Methods & Item & Result & No. (\%) & $\begin{array}{l}\text { Grade/ } \\
\text { remark }\end{array}$ \\
\hline \multirow[t]{12}{*}{ Tube } & Le(a) & - & $18(100.0)$ & Acceptable \\
\hline & & $1+$ & 0 & \\
\hline & & $2+$ & 0 & \\
\hline & & $3+$ & 0 & \\
\hline & & $4+$ & 0 & \\
\hline & Le(b) & - & $17(94.4)$ & Acceptable \\
\hline & & $1+$ & $1(5.6)$ & Unacceptable \\
\hline & & $2+$ & 0 & \\
\hline & & $3+$ & 0 & \\
\hline & & $4+$ & 0 & \\
\hline & Conclusion & Le(a-b-) & $17(94.4)$ & Acceptable \\
\hline & & Le $(a-b+)$ & $1(5.6)$ & Unacceptable \\
\hline \multirow[t]{11}{*}{ CAT } & Le(a) & - & $3(100.0)$ & Code 501 \\
\hline & & $1+$ & 0 & \\
\hline & & $2+$ & 0 & \\
\hline & & $3+$ & 0 & \\
\hline & & $4+$ & 0 & \\
\hline & Le(b) & - & $3(100.0)$ & Code 501 \\
\hline & & $1+$ & 0 & \\
\hline & & $2+$ & 0 & \\
\hline & & $3+$ & 0 & \\
\hline & & $4+$ & 0 & \\
\hline & Conclusion & Le(a-b-) & $3(100.0)$ & Acceptable \\
\hline
\end{tabular}

Abbreviation: CAT, column agglutination test. 
Table 2. Results of Duffy antigen typing $(n=20)$

\begin{tabular}{|c|c|c|c|c|}
\hline Methods & Item & Result & No. (\%) & $\begin{array}{l}\text { Grade/ } \\
\text { remark }\end{array}$ \\
\hline \multirow[t]{11}{*}{ Tube } & Fy(a) & - & 0 & \\
\hline & & $1+$ & 0 & \\
\hline & & $2+$ & $4(26.7)$ & Acceptable \\
\hline & & $3+$ & $9(60.0)$ & Acceptable \\
\hline & & $4+$ & $2(13.3)$ & Acceptable \\
\hline & $\mathrm{Fy}(\mathrm{b})$ & - & $15(100.0)$ & Acceptable \\
\hline & & $1+$ & 0 & \\
\hline & & $2+$ & 0 & \\
\hline & & $3+$ & 0 & \\
\hline & & $4+$ & 0 & \\
\hline & Conclusion & Fy $(a+b-)$ & $15(100.0)$ & Acceptable \\
\hline \multirow[t]{11}{*}{ CAT } & Fy(a) & - & 0 & \\
\hline & & $1+$ & 0 & \\
\hline & & $2+$ & $2(40.0)$ & Code 501 \\
\hline & & $3+$ & $3(60.0)$ & Code 501 \\
\hline & & $4+$ & 0 & \\
\hline & $\mathrm{Fy}(\mathrm{b})$ & - & $5(100.0)$ & Code 501 \\
\hline & & $1+$ & 0 & \\
\hline & & $2+$ & 0 & \\
\hline & & $3+$ & 0 & \\
\hline & & $4+$ & 0 & \\
\hline & Conclusion & $\mathrm{Fy}(\mathrm{a}+\mathrm{b}-)$ & $5(100.0)$ & Acceptable \\
\hline
\end{tabular}

Abbreviation: CAT, column agglutination test.

항원 결과를 입력하지 않고 $\mathrm{Fy}(\mathrm{b})$ 항원 결과를 음성, 최종 판정을 $\mathrm{Fy}(\mathrm{a}-\mathrm{b}-)$ 결과를 입력하였고, 다른 한 기관에서는 $\mathrm{Fy}(\mathrm{b})$ 항원 결 과만 입력하고 Fy(a) 항원 및 최종 판정 결과를 입력하지 않아 분 석에서 제외하였다. 의도된 정답은 $\mathrm{Fy}(\mathrm{a}+\mathrm{b}-)$ 로, 분석에 포함된 20 개 기관의 정답률은 $100 \%$ (20/20)였다. Duffy 항원형 검사에서 는 원주응집법을 5 기관에서 사용하고 있었고 15 기관은 시험관법 을 사용하고 있었다. $\mathrm{Fy}(\mathrm{a})$ 항원에 대한 응집강도는 $2+$ (6기관), $3+$ (12기관), 4+ (2기관)으로 응답하였고, $\mathrm{Fy}(\mathrm{b})$ 항원에 대해서는 모두 음성 결과를 입력하였다. 시험관법 결과를 입력한 15 개 기관 의 경우 혈구 응집강도에서 모두 acceptable 판정에 해당되었다 (Table 2).

Kidd 항원의 경우, 참여한 23 개 기관 중 한 기관에서 Jk(a) 항 원 결과만 입력하고 그 외 $\mathrm{Jk}(\mathrm{b})$ 항원 및 최종 판정을 입력하지 않 아 결과 분석에서 제외하였다. 의도된 정답은 $\mathrm{Jk}(\mathrm{a}+\mathrm{b}+)$ 였고, 분
Table 3. Results of Kidd antigen typing ( $n=22$ )

\begin{tabular}{|c|c|c|c|c|}
\hline Methods & Item & Result & No. (\%) & $\begin{array}{l}\text { Grade/ } \\
\text { remark }\end{array}$ \\
\hline \multirow[t]{11}{*}{ Tube } & $J k(a)$ & - & 0 & \\
\hline & & $1+$ & $5(29.4)$ & Acceptable \\
\hline & & $2+$ & $8(47.1)$ & Acceptable \\
\hline & & $3+$ & $4(23.5)$ & Acceptable \\
\hline & & $4+$ & 0 & \\
\hline & $J k(b)$ & - & 0 & \\
\hline & & $1+$ & $2(11.8)$ & Acceptable \\
\hline & & $2+$ & $8(47.1)$ & Acceptable \\
\hline & & $3+$ & $3(17.6)$ & Acceptable \\
\hline & & $4+$ & $4(23.5)$ & Acceptable \\
\hline & Conclusion & $\mathrm{Jk}(\mathrm{a}+\mathrm{b}+)$ & $17(100.0)$ & Acceptable \\
\hline \multirow[t]{11}{*}{ CAT } & $J k(a)$ & - & 0 & \\
\hline & & $1+$ & 0 & \\
\hline & & $2+$ & 0 & \\
\hline & & $3+$ & 0 & \\
\hline & & $4+$ & $5(100.0)$ & Code 501 \\
\hline & $J k(b)$ & - & 0 & \\
\hline & & $1+$ & 0 & \\
\hline & & $2+$ & 0 & \\
\hline & & $3+$ & $3(60.0)$ & Code 501 \\
\hline & & $4+$ & $2(40.0)$ & Code 501 \\
\hline & Conclusion & $J k(a+b+)$ & $5(100.0)$ & Acceptable \\
\hline
\end{tabular}

Abbreviation: CAT, column agglutination test.

석에 포함된 22 개 기관의 정답률은 $100 \%$ (22/22)였다. 검사법은 원주응집법이 5 기관, 시험관법이 17 기관이었다. $\mathrm{Jk}(\mathrm{a})$ 항원에 대 한 응집강도는 $1+$ (5기관), $2+$ (8기관), $3+$ (4기관), $4+$ (5기관)이 었으며, Jk(b) 항원에 대해서는 $1+$ (2기관), 2+ (8기관), 3+ (6기 관), $4+$ (6기관)으로 Duffy 항원에 비해서는 응집강도가 다양하게 나타났으나, 시험관법 결과를 입력한 17 개 기관 모두 acceptable 판정에 해당되었다(Table 3).

\section{고찰}

본 연구에서는 국내 임상검사실을 대상으로 새롭게 시행된 Lewis, Duffy, Kidd 항원형 검사에 대한 외부정도관리 시범사업 결과를 기술하였다. Lewis, Duffy, Kidd에 대한 정답률은 각각 $95.2 \%, 100.0 \%, 100.0 \%$ 로 높은 결과를 보여주었고, 이를 근거 
로 이후 정식사업으로 진행하기에 큰 무리가 없는 것으로 판단되 었다. 미국 식품의약국(U.S. Food and Drug Administration)에 서는 주요 혈액형 항원의 면역원성과 임상적 의의를 고려하여 비 예기항체 검사 시 다음 항원에 대한 항체 여부를 포함하여 확인할 것을 권고하고 있다: D, C, E, c, e, M, N, S, s, P1, Le(a), Le(b), K, $\mathrm{k}, \mathrm{Fy}(\mathrm{a}), \mathrm{Fy}(\mathrm{b}), \mathrm{Jk}(\mathrm{a}), \mathrm{Jk}(\mathrm{b})$ [12]. 이 중 $\mathrm{K}$ 와 k항원의 경우 한국 인의 인종적 특성상 대다수가 $\mathrm{K}$ 항원 음성, $\mathrm{k}$ 항원 양성이기 때문에 anti-K가 생성되거나 K항원 양성 혈액이 수혈될 가능성이 매우 낮 아 K항원검사가 필요한 상황이 외국에 비해 매우 낮다. 이번 시범 사업에서는 기존에 보고된 비예기항체 빈도 및 전문가 자문을 바 탕으로 임상적 필요가 있다고 판단된 Le(a), Le(b), Fy(a), Fy(b), $\mathrm{Jk}(\mathrm{a}), \mathrm{Jk}(\mathrm{b})$ 를 우선 선정해 평가하였고[13], 향후 K항원을 제외 한 다른 혈액형 항원검사 항목도 추가로 확대 시행하는 것을 검토 중이다. 적혈구 항원검사는 환자에게 비예기항체가 동정되어 해당 항원 음성 혈액제제를 찾아야 할 때 필요한데, 큰 의료기관이 아니 면 시약을 유효기간 내에 충분히 사용하기가 어려울 수 있어 항원 검사를 직접 시행하는 검사실이 많지 않다. 그동안 이 검사항목에 대해 외부정도관리프로그램이 제공되지 않아 검사실 입장에서는 소수의 검사실 간 비교와 같은 방법을 사용해 대응하였으나, 향후 정식사업으로 확대 및 지속되면 국내 수혈의학분야의 외부정도관 리에 큰 기여를 할 수 있을 것으로 기대된다.

Lewis 항원은 19번 염색체에 있는 FUT2, FUT3 유전자에 의하 여 표현형이 결정되며, 적혈구에서 바로 발현되지 않고 혈장으로 부터 흡착하는 항원이라는 특징이 있다[14]. Lewis 혈액형군의 두 항원인 Le(a) 및 Le(b)에 대한 항체는 국내 한 기관의 발표자료에 서는 각각 $7.8 \%, 1.8 \%$ 로 전체 빈도 순에서 3 위, 8 위를 차지할 정 도로 자주 발견되며, 항 -Le(a) 항체보다 자주 발견되는 항체는 Rh 혈액형군의 항원에 대한 항체 외에 없었다[13]. Lewis 혈액형 항 원에 대한 항체는 일반적으로는 임상적 의의가 낮아 설령 항체를 가지고 있다고 하더라도 굳이 해당 항원 음성 혈액제제 대신 항글 로불린 단계 교차시험에서 적합한 혈액을 주어도 충분하다는 의견 도 있으나[15], 드물지만 임상적으로 용혈수혈반응과 태아신생아 용혈성 질환을 일으킬 수 있다는 보고도 있다[16,17]. 따라서 임상 검사실에서 정확한 Lewis 항원형 검사를 실시할 수 있는 능력을 갖추는 것은 필수적이라고 할 수 있다.

Duffy 항원에 대한 항체는 용혈수혈반응과 태아신생아용혈성 질환 모두를 일으킬 수 있는 임상적으로 중요한 항체이다. 항원형 을 결정짓는 유전자는 1 번 염색체에 위치한 $A C K R 1$ 로 125 번 염 기가 구아닌인지 아데노신인지에 따라 $\mathrm{Fy}(\mathrm{a})$ 항원과 $\mathrm{Fy}(\mathrm{b})$ 항원 의 표현형이 결정된다. 그리고 Duffy 표현형은 인종에 따라 그 빈 도 차이가 있어, 특히 흑인에서 Fy(a-b-) 표현형이 높아 $60 \%$ 이 상을 차지하나 다른 인종에서는 매우 드문 것으로 알려져 있다. 이
는 Fy(a-b-) 표현형이 말라리아 감염으로부터 저항성을 보이기 때문에 생기는 진화적 선택으로 이해하고 있다[18]. 한국인에서는 $99 \%$ 이상 Fy(a)는 양성이며 약 $80 \%$ 에서 $\mathrm{Fy}(\mathrm{b})$ 는 음성이다[19]. 그러나 국내에서도 환자들의 인종 구성이 점차 다양해짐에 따라 $\mathrm{Fy}(\mathrm{a}-\mathrm{b}-)$ 표현형을 가진 환자를 접하는 경우가 점차 늘어나고 있 다. 따라서 Duffy 표현형을 정확하게 검사할 수 있는 능력을 갖추 는 것이 점차 중요해지고 있다.

Kidd 항원은 18 번 염색체에 위치한 SLC14A1 유전자에 의하 여 표현형이 결정되며, 한국인에서의 빈도는 Jk(a-b-)는 드물며, $\mathrm{Jk}(\mathrm{a}+\mathrm{b}+), \mathrm{Jk}(\mathrm{a}+\mathrm{b}-), \mathrm{Jk}(\mathrm{a}-\mathrm{b}+)$ 가 각각 $50.8 \%, 20.9 \%, 28.3 \%$ 정도로 분포하고 있다[19]. Kidd 항원에 대한 항체도 용혈수혈반 응과 태아신생아용혈성 질환 모두를 일으킬 수 있어 임상적으로 중요한 항체이다. 앞에서 언급한 Duffy 항원과 함께 Kidd 항원은 겸상적혈구질환이나 지중해빈혈처럼 만성적으로 수혈을 받아야 하는 환자들에서 미리 항원 맞춤형 수혈을 권장하는 혈액형이다 [20]. 이러한 혈색소 이상질환들은 아직까지는 국내에서는 거의 발견된 적이 없으나, 향후 인종 구성이 다양해짐에 따라 국내에서 도 점차 그 빈도가 늘어날 것으로 예측되므로 임상검사실에서는 이에 대한 준비를 미리 해놓는 것이 필요할 것으로 생각된다[21].

현재 $\mathrm{ABO}, \mathrm{RhD}$ 항원 이외에 혈액형 항원에 대해서는 Rh CcEe 항원에 대해서만 신빙도조사를 실시하고 있다. 이 항원들에 대해 서는 혈구 응집강도와 최종 판정 데이터를 받으나, 혈구 응집강 도에 대해서는 표준화가 되어있지 않고, 실제 결과 보고를 할 때 에도 응집강도는 검사실 내부에서만 보존하고 양성/음성만 보고 하는 경우가 많으므로 응집강도에 대해서는 education 항목으 로 운영을 하고 있다. 대표적인 국외 신빙도조사 기관인 미국병리 협회(College of American Pathologists)에서도 혈구 응집강도 에 대해서는 판정기준으로 삼지 않는다. 따라서 본 연구에서 시범 사업으로 진행한 Lewis, Duffy, Kidd 항원형 검사에서도 이와 마찬 가지로 최종 결과만 판정대상으로 삼고, 혈구 응집강도에 대해서는 education 항목으로 운영을 하는 것이 합리적인 방안으로 생각된다.

결론적으로, 본 연구에서는 기존의 수혈의학분야 신빙도조사사 업에 더하여 Lewis, Kidd, Duffy의 세 혈액형 항원에 대한 항원형 검사에 대한 신빙도조사 시범사업을 실시하였다. 대부분의 참여기 관에서 만족스러운 결과를 보여 해당 검사는 정식사업으로 실시하 기에 무리가 없는 것으로 판단되어 2021년도에는 정식 신빙도조 사사업 항목으로 전환되었다. 본 연구진에서는 신빙도조사 검사항 목 확대의 일환으로 2021년도에는 항-D 항체역가검사에 대한 시 범사업을 준비하고 있으며, 향후 다른 혈액형 항원검사항목도 추 가하는 것을 검토하고 있다. 


\section{감사의 글}

이 논문은 대한임상검사정도관리협회의 2020년 학술연구비 지 원을 받아 시행한 결과를 바탕으로 작성되었다(과제번호 2020-5).

\section{ORCID}

Yousun Chung https://orcid.org/0000-0002-5197-6340
Jin Seok Kim https://orcid.org/0000-0003-0166-2084 John Jeongseok Yang

https://orcid.org/0000-0002-7739-1009

Hyungsuk Kim https://orcid.org/0000-0002-0574-9200

Sang-Hyun Hwang https://orcid.org/0000-0003-3201-5728

Heung-Bum Oh https://orcid.org/0000-0001-6728-4640

Dae-Hyun Ko https://orcid.org/0000-0002-9781-0928

\section{REFERENCES}

1. Yang JJ, Kim JS, Lim YA, Kim H, Ko DH. Annual report of the Korean Association of External Quality Assessment Service on transfusion medicine (2019). Lab Med Qual Assur 2020;42:112-20.

2. Lee YW. Annual report of the Korean Association of External Quality Assessment Service on general chemistry (2019). Lab Med Qual Assur 2020;42:97-111.

3. Lee YK, Kim YM; Korean Association of External Quality Assessment Service, the Routine Hematology Program. Annual report of the Korean Association of External Quality Assessment Service on routine hematology (2019). Lab Med Qual Assur 2020;42:55-62.

4. Lee SY. Report of the Korean Association of External Quality Assessment Service on metabolite testing (2018-2019). Lab Med Qual Assur 2020;42:10-25.

5. Chung HJ, Moon HW, Yi J. Report of the Korean Association of External Quality Assessment Service on autoimmune testing (2018-2019). Lab Med Qual Assur 2020;42:1-9.

6. Kim HK, Ko DH, Jeong TD, Shin ES, Kim JH, Chun S. Report of the Korean Association of External Quality Assessment Service on therapeutic drug monitoring and toxicology (2015-2019). Lab Med Qual Assur 2020;42:183-93.

7. Jeon S, Won EJ, Lee YJ, Kim MJ, Shin MG, Shin JH. Report of the Korean Association of External Quality Assessment Service on clinical parasitology (2018-2019). Lab Med Qual Assur 2020;42:177-82.

8. Cho EJ, Choi AR, Ryu JH, Yun SJ, Oh EJ. Report of the Korean Association of External Quality Assessment Service on hepatitis serology (2018-2019). Lab Med Qual Assur 2020;42:166-76.

9. Jeon CH, Kim SG, Bae YC. Annual report of the Korean Association of External Quality Assessment Service on urinalysis and fecal occult blood testing (2019). Lab Med Qual Assur 2020;42:157-65.

10. Seong MW, Kim M, Shin HS, Cho SI, Park SS. Three-year experience of an external proficiency testing survey for nextgeneration sequencing-based testing for germline mutation. Lab Med Qual Assur 2020;42:48-53.

11. Yang JJ, Kim JS, Chung Y, Kim H, Ko DH, Hwang SH, et al. Exploratory investigation for improvement of the external quality assessment scheme for transfusion medicine. Lab Med Qual Assur 2020;43:19-24.

12. Cohn CS, Delaney M, Johnson ST, Katz LM. Technical manual. 20th ed. Bethesda (MD): American Association of Blood Banks, 2020.

13. Ok SJ, Kim SY, Kim IS, Lee EY, Kim HH. Eleven years' experience with unexpected antibody screening tests including a Dia cell in transfusion candidates. Korean J Blood Transfus 2013;24:64-70.

14. Combs MR. Lewis blood group system review. Immunohematology 2009;25:112-8.

15. Australian and New Zealand Society of Blood Transfusion. Guideline for transfusion and immunohaematology laboratory practice. Sydney: The Australian \& New Zealand Society of Blood Transfusion, 2016.

16. Delk AA, Gammon RR, Alvarez H, Benitez N, Bright F. A hemolytic transfusion reaction caused by an unexpected Leb 
antibody. Lab Med 2021 Jan 5 [Epub]. https://doi.org/10.1093/labmed/lmaa070.

17. Duncan V, Pham HP, Williams LA 3rd. A possible case of a haemolytic transfusion reaction caused by anti-Le(a) antibody. Blood Transfus 2015;13:535-6.

18. Nathalang O, Intharanut K, Siriphanthong K, Nathalang S, Kupatawintu P. Duffy blood group genotyping in Thai blood donors. Ann Lab Med 2015;35:618-23.

19. Kim IT, Suh IB, Ma KR, Lim CS, Kim YK, Lee KN. The genotyping of Kell, Duffy, and Kidd system in Korean. Korean J Blood Transfus 2003;14:9-19.

20. Compernolle V, Chou ST, Tanael S, Savage W, Howard J, Josephson CD, et al. Red blood cell specifications for patients with hemoglobinopathies: a systematic review and guideline. Transfusion 2018;58:1555-66.

21. Lee HJ, Shin KH, Kim H, Jeong S, Kong SG, Kim HH. A case of sickle cell anemia with a lack of high frequency red blood cell antigen. Korean J Blood Transfus 2018;29:188-93. 